\title{
Kajian Dinamika Kesetaraan Gender Pada Film Ki dan Ka
}

\author{
Widarti $^{1}$, Yasir Riady ${ }^{2}$ \\ ${ }^{1}$ Universitas Bina Sarana Informatika \\ e-mail: widarti.wdr@bsi.ac.id \\ ${ }^{2}$ UPBJJ UT Jakarta \\ e-mail: yasir@ecampus.ut.ac.id \\ Cara Sitasi: Widarti, Yasir R (2021) Kajian Dinamika Kes taraan Gc der Pada Film Ki dan Ka 2021 21(2), \\ 157-166 Retrieved from https://doi.org/10.31294/jc.v19i2

\begin{abstract}
Patriarchal culture has long been rooted Inso iety, regulating all aspects of life for both men and women. One of them is married life. Men ana von en are equally required to fulfill traditional roles according to patriarchal standards. Men are require to pro raneadwinners, while women only do domestic work. Women work only to support their husbands. Ki $\mathrm{K}$ K film ries to show a different role from what is usual in society. So this film aims to describe the visyalization d the dynamics of gender equality in the Ki \& Ka film. The theory used in this research is the Identity Ne statign Theory by Stella Ting-Toomey. This theory seeks to explore the ways in which identity is negotiq d in inten ctions with other people, especially in different cultures. The method used is semiotic analysis, by tryin. The results showed that Ki and Ka were able to show the dynam, yof identity negotiations such as efforts to fit in with the environment, showing selfidentity and the turmoil of people around when gender equality was trying to be applied in society.
\end{abstract}

Keywords: Patriarchy, Film Ki \& Ka, Feminism

\section{PENDAHULUAN}

Membahas Patriarki tidak akan pernah ada habisnya, budaya yang telah berakar di dunia ini selalu menjadi kontroversi di belahan dunia mana saja. Menurut Sakina, (Sakina, 2017), menyatakan bahwa praktik patriarki masih terus berlangsung di tengah banyaknya gerakan feminis dan di saat para perempuan gencar untuk terus menyuarakan berbagai hak perempuan. Budaya ini terbukti merugikan baik laki-laki maupun perempuan. Budaya patriarki berawal sejak sebelum manusia menuju era modernisasi. Budaya patriarki telah ada sejak sebelum revolusi industri.

Menurut Asal Usul Keluarga, Kepemilikan Pribadi dan Negara (Fredrick Engels 2011:38) budaya patriarki muncul pada zaman peralihan yaitu peralihan zaman paleolitikum dan zaman logam yang dimulai dari adanya aktivitas bercocok tanaman holtikultura yang dilakukan oleh perempuan, kemudian domestifikasi binatang buruan menjadi ternak hingga ditemukannya baja dan api yang dibuat menjadi bajak sehingga dapat mengelola tanah lebih luas. Pembajakan ini dilakukan oleh laki-laki karena perempuan tidak bisa lagi mengombinasikan pekerjaan memelihara anak dengan produksi pertanian dan hal-hal lain yang melatarbelakangi perempuan tidak membajak dikarenakan proses evolusi tubuh perempuan yang berubah pada zaman holtikultura. Pembajakan mendapatkan hasil yang banyak sehingga terjadi akumulasi modal dan menyebabkan surplus pada laki-laki sehingga muncul kepemilikan pribadi. Surplus inilah yang memulai adanya budaya patriarki yang mana perempuan mulai didomestifikasi dan hanya difungsikan sebagai alat reproduksi untuk menghasilkan generasi yang nantinya generasi tersebutlah yang akan dijadikan tenaga kerja.

Penelitian yang dilakukan oleh (Nimrah \& Sakaria, 2015)015), menyatakan bahwa sistem patriarki menyebabkan laki-laki seringkali mendominasi perempuan dan perempuan menjadi orang kedua setelah laki-laki sehingga kesempatan perempuan menjadi terbatasi.

Patriarki merupakan tata kekeluargaan berdasar pada garis keturunan dan berkaitan dengan sistem sosial. Ayah dianggap sebagai pihak nomor satu atau utama di dalam keluarga sehingga berkuasa atas keluarganya, harta yang dimiliki serta menjadi pencari nafkah utama. Laki-laki juga menjadi penentu pengambilan keputusan di dalam keluarga. Patriarki pada akhirnya dipahami sebagai ideologi atau kepercayaan yang meletakan laki-laki sebagai pemilik kekuasaan atau memiliki kedudukan lebih tinggi dibandingkan dengan perempuan. Perempuan pada akhirnya pun dianggap sebagai harta milik lakilaki yang harus dikuasai dan patuh pada peranan lakilaki (Sari \& Haryono, 2019). Feminisme sering kali disalahtafsirkan. Pertama, sebagai gerakan dari Barat, atau bahkan lebih dari itu diidentifikasi sebagai Barat. Kedua, yang melanjutkan kesalahtafsiran pertama yaitu feminisme merupakan gerakan perempuan yang 
membenci laki-laki, pengikut seks bebas, bahkan lesbian (Wadud, 2015).

PBB secara aktif mencoba membuka mata dunia dengan membangun kampanye yang mengajak laki-laki turut membantu perjuangan ini. PBB berusaha mengedukasi bahwa perjuangan ini bukan milik perempuan saja, tapi juga laki-laki melalui berbagai kegiatan (https://www.unocha.org/story/gender-equality-notonly-women-issue-it-everyon(Zewitra,

2018).(Prabasmoro \& Aquarrini, 2006) Pemahaman dasar atas feminisme ini penting untuk melihat dengan lebih bening bahwa feminisme bukanlah semata-mata milik perempuan. Laki-laki maupun perempuan yang menyadari adanya ketimpangan struktur pada dasarnya adalah seorang feminis, tidak masalah jika ia tidak ingin dilabeli atau melabeli diri dengan feminis, tetapi mata terbuka ka ketimpangan ini menjadikannya fem (Prabasmoro, 2007:23).(Permana, 2017

Banyak kampanye dilakukrn, meski hingga saat ini kesetaraan gender masih aygat jaun dari tercapai. Aturan-aturan yan mo ngek ng perempuan khususnya semakin banyak. Don pernikahan, peran perempuan turut diatur. Ada standar ganda dalam peran perempuan sebagal seorang istri dan ibu. Terdapat beberapa penelitian yang fokus mengkaji tentang kesertaraan perempuan. Pada tahun 2017, Permana melakukan penelitian tentang perempuan dalam kampanye anti korupsi dimana hasilnya menunjukan bahwa perempuan digambarkan sebagai sosok ibu dalam keluarga dan organisasi yang menjadi teladan dalam konteks kampanye yang dipublikasikan (Permana, 2017). Zewitra pada tahun 2018 meneliti tentang pilihan kata Manifestasi Konsep Kesetaraan Gender dalam Wacana Kampanye Un Women. Hasilnya menunjukan bahwa kesetaraan gender dipandang sebagai kondisi saat perempuan ditempatkan pada posisi setara dengan laki-laki, dapat membawa perubahan di masa depan dan menjadi tanggung jawab semua pihak (Zewitra, 2018).

Kuatnya budaya patriarki pada akhirnya membuka pandangan perempuan mengenai keinginan untuk menjadi seorang istri yang bebas secara finansial dan memperoleh hak yang setara dengan laki-laki. Peran sebagai istri dengan penghasilan besar tentu berdampak pada tidak perlunya ia menggantungkan beban finansialnya kepada sang suami. Terlebih jika kebutuhan pengeluaran rumah tangga cukup tinggi dan tidak bisa jika hanya mengandalkan gaji suami. Meskipun dalam budaya patriarki hal tersebut masih terkesan tidak lazim. Idealnya, seorang suami menjalankan perannya sebagai kepala keluarga yang memiliki kewajiban atas memenuhi segala kebutuhan rumah tangga sedangkan seorang istri berkewajiban mengatur rumah tangga sebaik yang ia bisa. Menurut UU No. 1 Tahun 1974 Pasal 31 (Arivia, 2006) Paragraf 3: "Laki-laki adalah kepala rumah tangga dan perempuan adalah ibu rumah tangga." Pada Pasal 34, paragraf 1 dan 2: "Laki-laki mempunyai kewajiban untuk menyediakan keperluan rumah tangga karena ia menyanggupi, dan perempuan mempunyai kewajiban mengatur rumah tangga sebaik mungkin."

Masyarakat selalu beranggapan bahwa seorang pria harus kuat,beroni, dapat mencari nafkah sedangkan wanita bruslah lembut, halus, dan mengurus rumab tang. a. S lama bertahun-tahun terjadi pengkou kar da o/ peran gender yang mengharu, an se rang pria untuk berkerja dan wanitanieng rus ru rah tangga. Di mana seharusnya pri dan wan $y$ itu memiliki kesetaraan gender. Ke ludukar pria dan wanita harus sama, hal tersebut juga ercentum dalam UU No.1 tahun 1974 tentang P. kawinan bab VI pasal 31.1 yang berbunyi Hak dan kedudukan istri adalah seimbang dengan hak dan kedudukan suami dalam kehidupan dalam rumah tangga dan pergaulan hidup bersama dalam masyarakat (Mewengkang, 2020).

Namun ternyata tidak semua istri berperan sebagai pengatur rumah tangganya di rumah, yaitu dimana seorang istri memiliki kedudukan yang tinggi di tempatnya bekerja sehingga harus bertukar tempat dengan suaminya dalam mengambil peranan rumah tangga. Penyebab hal ini biasanya adalah adanya tuntutan kewajiban yang lebih besar di ranah pekerjaan dan sang istri harus menyiasati bagaimana kehidupan rumah tangga dan kehidupan pekerjaan dapat tetap berjalan beriringan. Entah dengan melakukan sebuah kesepakatan ataupun negosiasi dengan sang suami. Jabatan istri yang lebih tinggi dibanding suaminya saja sudah bisa dijadikan bahan pembicaraan oleh masyarakat ataupun keluarga mereka, apalagi ketika peran sang istri berubah sepenuhnya menjadi pencari nafkah sedangkan sang suami mengurusi semua pekerjaan rumah di tengah budaya patriarki yang masih kental di wilayah bumi ini.

Banyak yang menaruh perhatian pada konteks menjadi perempuan. Seluruh anggapan bagaimana seharusnya menjadi perempuan pada kenyataannya tak selalu berdampak positif bagi para perempuan. Tidak sedikit perempuan frustrasi karena nasihat-nasihat asumtif yang menjadi sugesti sekaligus tuntutan yang dilontarkan (http://magdalene.co/). Peristiwa ini meliputi hampir di seluruh bagian dunia sehingga secara sadar maupun tidak dapat membatasi ruang lingkup perempuan terhadap segala hal. Dewasa ini muncul sekelompok perempuan di berbagai negara bagian untuk menyuarakan kesetaraan gender. Hal ini didukung oleh sebagian kecil perempuan di muka bumi. Lebih banyak kontra didapatkan dari berbagai aksi dan juga kampanye mengenai kesetaraan gender. Bagaimana tidak, kebanyakan perempuan seolaholah sudah memaklumi berbagai batasan yang diberikan untuk dirinya sedari lahir. 
Di suatu kondisi umum perempuan memang berbeda dengan laki-laki, namun ada kondisi khusus yang dimiliki perempuan yang membuatnya berbeda. Nilai dan cara berada perempuan dikonstruksikan oleh pengalaman perempuan yang melahirkan, menyusui, merawat, dan mempunyai tingkat kesensitifan serta kepedulian yang besar (Arivia, 2006). Berdasar kutipan tersebut menggambarkan bahwa seorang perempuan tentu dinilai sebagai lemah lembut, sabar, tidak dominan, dan lain sebagainya. Akan terasa tidak umum ketika ada perempuan yang suka teriak-teriak, kasar, dan lain sebagainya karena sifat-sifat kebalikan tersebut secara tidak langsung dianggap sikap laki-laki. Di dunia ini, segala hal yang tidak seperti biasanya akan dianggap sebagai sebuah ketidaknormalan. Perempuan diartikan harus bisa memasak, harus memiliki karir yang lebih rendah dari pada pasangannya, harus lemah gemulai, harus bertz ur lembut, dan harus-harus lainnya. Ketik? tida memenuhi kriteria tersebut maka ferc npuan dianggap "belum perempuan”.

Apabila seorang pria memula couah rumah

tangga dirinya harus bertangg ng. awab penuh akan sang istri dan anak-anaknya jas ammentun rohani. Hal ini tidak lepas dari peran $m$ skulinisme dalam pembagian gender role, karena pembagian gender role yang mengharuskan seorang pria maskulin maka dari itu banyak dari pria yang enggan untuk melakukan pekerjaan rumah tangga termasuk mengurus anak. Dikarenakan maskulinisme sendiri menuntut seorang pria menjadi pencari nafkah, bersifat tegas, dan mandiri (Abbott, 1992).

Berdasarkan pengamatan peneliti, dari tiga laki-laki yang peneliti wawancarai sebagai pra observasi penelitian, ketiga laki-laki tersebut menyatakan bahwa mereka tumbuh dengan didikan dari orang tua bahwa laki-laki tidak boleh menangis. Dari tiga perempuan yang peneliti wawancara, kesemuanya mengatakan bahwa mereka tumbuh dengan didikan dari orang tua bahwa karir perempuan tidak boleh lebih tinggi dari suaminya kelak sehingga berdampak pada cita-cita yang tidak pernah tercapai begitu saja.

Masalah feminitas dan maskulinitas menjadi topik yang tidak akan pernah selesai pembahasannya. Apalagi jika ada pasangan perempuan dan laki-laki yang memutuskan untuk bertukar posisi di dalam rumah tangga, yaitu perempuan yang mencari nafkah di luar rumah sedangkan laki-laki menjadi bapak rumah tangga. Hal ini muncul dalam visualisasi film dari negara India yaitu Ki and Ka. Menurut UU No.8 tahun 1992, film merupakan karya cipta seni yang menjadi media komunikasi dan dibuat berdasar asas sinematografi, kemudian direkam sehingga dapat dipertunjukan atau ditayangkan (Yusriana \& Nurinsa, 2020).

Negara India memiliki berbagai kemiripan dengan Indonesia. Mulai dari namanya yang memiliki arti yang sama hingga penyebutan mata uang yang hampir mirip, Rupee dan Rupiah. Kultur patriarki di India juga mengakar layaknya kultur di Indonesia pula. Perbedaan film India $\mathrm{Ki}$ and $\mathrm{Ka}$ dengan film lainnya adalah film ini menceritakan kehidupan pernikahan Kia dan Kabir yang bertukar posisi secara gender dalam rumah tangga. Kia sebagai wanita karir yang menjadi tulang punggung keluarganya sedangkan Kabir memiliki kuasa penuh pada mengatur rumah dalam artion memasak, mencuci baju, belanja, hingga engatu keuangan rumah tangga.

Hal yang eparik d anding film yang lain adalah bagai, ana fil inj menyuguhkan pesan yaitu lingkunon ya o cencerung mendukung kekuatan peren puan dalan egala hal di tengah kekuatan lakilaki vang lianggap tidak sebanding. Di sini igam dron bahwa perempuan dan bahkan laki-laki menung sistem pernikahan yang terdapat posisi ebalikan tugas gender di dalam suatu rumah tangga. Di area India yang masih termasuk area Asia ini masih kental dengan budaya patriarki seperti budaya Indonesia.

Pemeran utama dalam film ini yaitu Kareena Kapoor dan Arjun Kapoor yang merupakan aktris dan aktor papan atas di India yang film-filmnya sering diputar di pertelevisian Indonesia. Respon orang Indonesia terhadap film ini memang tinggi terbukti dari jumlah tayangan di beberapa website nonton film daring. Seperti di IndoXXI film berdurasi 123 menit ini telah ditonton sebanyak 4004 kali, Nonton 21 Online 60 tontonan namun mendapatkan rating sebanyak 7/10 yang terhitung besar jika dibandingkan dengan rating film lainnya. (https://nonton21.online/ki-and-ka-2016/, diakses pada 12 Oktober 2020). Sedangkan di situs Film keren 21 terdapat 3660 sedangkan 2740 diantaranya memberikan bintang lima pada film ini (https://www.filmkeren21.co/ki-and-ka, diakses pada 10 Oktober 2020). Di situs Nonton 21 terdapat 2421 kali tontonan (http://www.nonton21.net/komedi/nonton-ki-and-ka2016/, diakses pada 25 September 2020). Film garapan sutradara R. Balki ini memiliki 3900 kali tontonan di Layar Kaca 21 (http://lk21.pw/ki-ka2016/, 27 September 2020).

Sejak dirilis di 1 April 2016 membuat film ini masih hangat diperbincangkan. Berdasar data yang diperoleh terkait jumlah penonton di beberapa situs online maka membuktikan bahwa film India Ki and Ka mendapatkan cukup banyak perhatian. Kajian mengenai bagaimana perempuan digambarkan di media telah dilakukan oleh Yusriana dan Zulfiningrum pada tahun 2016. Perempuan dan media memiliki hubungan dimana dominasi isi media adalah perempuan yang ditujukan atas kepentingan tertentu, misalnya: objek seksual maupun alat untuk memperoleh keuntungan (Yusriana \& Zulfiningrum, 2016).

Dari hasil telaah peneliti, terdapat beberapa penelitian yang objek penelitiannya adalah film Ki\&Ka. Pada tahun 2017. A Widyawati meneliti 
Representasi Peran Gender dalam Film India Ki \&Ka. Objek yang dikaji adalah Tokoh Kabir dan metode yang digunakan adalah Semiotika Roland Barthes. Hasil penelitiannya menunjukan bahwa pada film ini terjadi pertukaran peran gender antara suami istri dan Kabir terlihat sebagai sosok pria maskulin walaupun melakukan pekerjaan domestik (Widyawati, 2017). Tahun 2018, Nurotin melakukan penelitian Representasi Radikal pada Tokoh Kia di Film Ki\&Ka dimana metodeny adalah analisis wacana kritis. Hasilnya, bentuk feminism radikal meliputi pertentangan atas pelecehan perempuan, penolakan reproduksi alamiah atau tuntutan perempuan harus menjadi ibu dan menentang peran gender dari sisi laki-laki dan perempuan (Nurotin, 2018). Kebaharuan penelitian ini adalah untuk mendeskripsikan bagaimana representasi dinamika kesetaraan gender ditampilkan dalam film Ki \& Ka.

Penelitian ini berusaha menjelaskan fenomena yang diteliti dengan menggunakan teori Negosiasi Identitas oleh Stella Ting-Toomey. Stelia Ting-Toomey mengeksplorasi cara-cara di nana identitas dinegosiasi dalam interaksi dengan on ng lain, terutama dalam berbagai bu ryas Identit. sesesorang selalu dihasilkan dari-inter. si sosial. Identitas atau gambaran refro si- iri p da diri seseorang dibentuk melalui neg sias pada saat menyatakan, memodifikasi, atau me gelak beragam bentuk identifikasi diri ataupun orang lain. Hal ini bermula dalam kehidupan keluarga, ketika kita mulai memperoleh berbagai identitas pribadi dan sosial. Misalnya saja, kita memulai hubungan untuk pertama kalinya dengan berbagai identitas sosial atau afiliasi kelompok seperti budaya, jenis kelamin, dan usia. Perkembangan permulaan identitas gender juga terjadi dalam keluarga. Dalam beberapa keluarga, misalnya, anak-anak belajar lebih bagaimana mengidentifikasi berbagai posisi dan peran sosial, sedangkan dalam keluarga lainnya, mereka dapat belajar untuk memikirkan diri mereka masing-masing lebih dari sekadar sebagai individu yang tidak dihubungkan dengan berbagai posisi atau peran tertentu (Vera, 2014)

Menurut Ting-Toomey (1999 : $40-45)$, terdapat sepuluh asumsi teoritis inti dari teori negosiasi identitas: (1) Dinamika utama dari identitas keanggotaan seseorang dalam suatu kelompok dan identitas pribadi terbentuk melalaui komunikasi simbolik dengan orang lain. (2) Orang-orang dalam semua budaya atau kelompok etnis memiliki kebutuhan dasar akan motivasi untuk memperoleh kenyamanan identitas, kepercayaan, keterlibatan, koneksi dan stabilitas baik level identitas berdasarkan individu maupun kelompok. (3) Setiap orang akan cenderung mengalami kenyamanan identitas dalam suatu lingkungan budaya yang familiar baginya dan sebaliknya akan mengalami identitas yang rentan dalam suatu lingkungan yang baru. (4) Setiap orang cenderung merasakan kepercayaan identitas ketika berkomunikasi dengan orang lain yang budayanya sama atau hampir sama dan sebaliknya kegoyahan identitas manakala berkomunikasi mengenai tematema yang terikat oleh regulasi budaya yang berbeda darinya.

(5)Seseorang akan cenderung merasa menjadi bagian dari kelompok bila identitas keanggotaan dari kelompok yang diharapkan memberi respon yang positif. Sebaliknya akan merasa berbeda/asing saat identitas keanggotaan kelompok yang diinginkan memberi respon yang negatif. (6) Seseorang akan mengharapkan nsi antarpribadi melalui kedekatan relasi y. $\mathrm{g}$ med ingful (misalnya dalam situasi yang ponduk, g p rsahabatan yang akrab) dan sebalikn akan nengalami otonomi identitas saat nereka menghadapi relasi yang separatis/terprsah. (7) Orang akan memperoleh kestabil n identitas alam situasi budaya yang dapat dipredil i dan akan menemukan perubahan identitas at oncang dalam situasi-situasi budaya yang tidak dipeary sebelumnya.

(8)Dimensi budaya, personal dan keragaman ruasi mempengaruhi makna, interpretasi, dan penilaian terhadap tema-tema atau isu-isu identitas tersebut. (9) Kepuasan hasil dari negosiasi identitas meliputi rasa dimengerti, dihargai dan didukung. (10) Komunikasi antarbudaya yang mindful menekankan pentingnya pengintegrasian pengetahuan antarbudaya, motivasi, dan ketrampilan untuk dapat berkomunikasi dengan memuaskan, tepat, dan efektif.

Film merupakan media yang efektif untuk melakukan propaganda, salah satunya adalah propaganda mempengaruhi ataupun menyebarkan sebuah faham maupun gerakan di sini mengenai feminisme.

\section{METODOLOGI PENELITIAN}

Penelitian ini menggunakan paradigma kritis sebagai titik poin berpikir dan memandang dunia. Paradigma ini digunakan pada penelitian yang fokus pada kekuasaan, ketidaksetaraan dan perubahan sosial. Metode yang digunakan adalah Semiotika oleh Roland Barthes. Alasan digunakan penelitian ini, pertama bahwa obyek yang akan dikaji untuk diungkap maknanya adalah tanda, lambang, bahkan simbol yang ada pada film India Ki and Ka. Kedua, model Roland Barthes mengupas secara dalam ketika memaknai sebuah film dengan berpijak pada: Penanda dan petanda; Gambar, index, dan simbol; serta Fenomena sosial mengenai bagaimana isu feminisme dikisahkan dalam film India $\mathrm{Ki}$ and $\mathrm{Ka}$.

Pemahaman kode menggunakan Teori Roland Barthes akan memudahkan pembaca menilai tingkatan konotasi sebuah teks. Barthes menghasilkan konstruksi lima macam kode yang berbeda, atau yang disebutnya secara lebih populer kode yang lima, yaitu: (1) Kode hermeneutik. Pada pengkodean ini, peneliti mendaftar beragam istilah formal berupa sebuah teka-teki yang kemudian 
dibedakan, diduga, diformulasikan, dipertahankan, dan akhirnya disingkapi. Singkatnya, kode hermeneutik berhubungan dengan makna dibalik wacana wacana dan seringkali disebut dengan suara kebenaran (The Voice of Truth). (2) Kode proairetik atau kode narasi. Merupakan tindakan naratif dasar yang tindakannya dapat terjadi dalam berbagai sikuen yang mungkin diindikasikan. Kode ini disebut suara empirik.

(3)Kode budaya. Sebagai referensi kepada sebuah ilmu atau lembaga ilmu pengetahuan. Biasanya orang mengindikasikan kepada tipe pengetahuan kemudian mengkonstruksikan budaya yang berlangsung pada kurun waktu tertentu yang diupayakan untuk diekspresikan. Kode ini disebut pula sebagai su ilmu. (4) Kode semantik. Kode ini merupakan sebuab kode relasi penghubung (medium-relatic $\mathrm{Ca}_{\text {. }}$ ), yang merupakan konotasi dari orang, tempat, o romg pertandanya adalah sebuah kar kto (sifat, tribut, predikat). Kode semantik adolan berba ai tanda yang dirancang dengan tujuan mo mori makna konotasi, misalnya: maskulin, em in, h bangsaan, kesukuan, loyalitas. (5) Kode si holik. Tema merupakan sesuatu yang tidak st bil dan dapat ditentukan bentuknya sesuai dengan perspektif yang digunakan.

\section{HASIL DAN PEMBAHASAN}

Representasi adalah konstruksi sosial yang mengharuskan kita mengeksplorasi pembentukan makna tekstual dan menghendaki penyelidikan tentang cara dihasilkannya makna oada beragam konteks. Representasi dan makna budaya memiliki materialitas tertentu. Mereka melekat pada bunyi, prasasti, objek, citra, buku, majalah, dan program televisi. Mereka diproduksi, ditampilkan, digunakan, dan dipahami dalam konteks sosial tertentu (Barker, 2004:9). Pada penelitian ini terdapat delapan objek scene yang menceritakan mengenai dinamika kesetaraan gender.

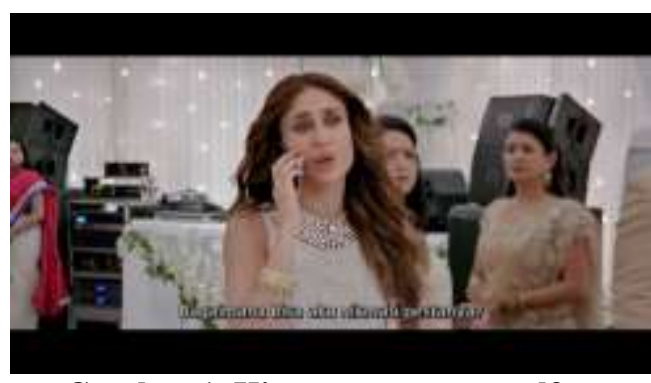

Gambar 1. Kia pura-pura menelfon

Objek penelitian yang pertama muncul dalam scene pemeran Kia yang mewakili perempuan sedang berpura-pura menelfon. Berikut adalah dialog yang disampaikan Kia:

"Halo? Halo? Bagaimana bisa aku menikmati pestanya? Sahabatku akan mati! Hari ini kebahagiaan, impian, identitas, dan kebebasannya musnah. Sebenarnya sekarang ini hari terakhirnya untuk hidup.
Mulai besok, dia akan jadi sandaran. Semacam penyangga. Ya, ya, penyangga. $Y a$, itu juga penting. Tapi seluruh dunia tetap akan bilang wow! Rumah yang indah! Siapa yang bilang sandaran yang jelek? Bukan, bukan. Aku suka pernikahan kok. Ini konsep yomo bagus. Tapi untuk apa aku harus abiska hidupku bersama seseorang yong ses lah 4 tahun akan menatap mataku

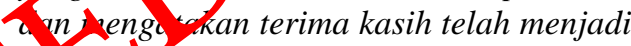
sa dara iku."

Pen 1 da pada adegan pertama ini adalah pemera, Kia menggunakan gaun putih sedang berflura-pura menelfon seseorang setelah ia mencabut kabel audio mixernya sehingga seluruh tamu yang tadinya menari jadi terpaku melihat ke arahnya dan mendengar percakapannya di telepon. Pemeran Kia menunjukan gesture tubuh yang membelakangi para tamu dan didukung dengan intonasi suara yang tinggi serta mimik wajah kesal sebagai bentuk ketidaksukaanya atas situasi yang ada.

Berdasar adegan yang ada didukung dengan komunikasi verbal dan non verbal yang nampak, dapat disimpulkan bahwa pertanda pada adegan 1 ini adalah tokoh perempuan yang tidak sepakat terhadap perbincangan orang tua mempelai pengantin mengenai perempuan yang menjadi penyangga lakilaki sebagai simbolis bahwa posisi perempuan dibawah laki-laki. Sebagai seorang perempuan, sosok Kia justru menyesali pilihan sahabatnya untuk menikah karena pada akhirnya akan menghambat karir perempuan. Dalam kacamata perempuan, sosok Kia merasa bahwa adanya pernikahan tidak akan membawa kebahagiaan bagi pihak perempuan sehingga sebagai perempuan Kia lebih memilih untuk fokus pada karirnya.

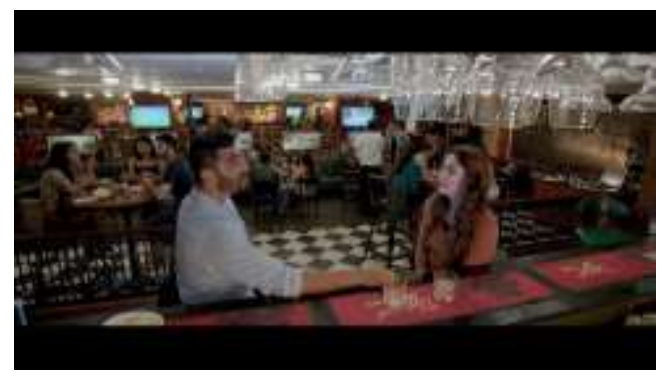

Gambar 2.

Adegan Dialog Kabir dan Kia tentang Peranan Ibu dalam Rumah Tangga

Pada objek penelitan kedua, peneliti memilih adegan dialog antara Kabir dengan Kia yang memperbincangkan tentang peranan ibu dalam rumah tangga dan keinginan anak laki-laki yang ingin sama dengan ibunya. Berikut ini dialog antara sosok lakilaki dan perempuan yang diwakili oleh Kabir dan Kia:

Kabir: Aku ingin jadi seperti ibuku. Kia: Maaf?

Kabir: Aku.. Ingin jadi seperti ibuku 
Penanda pada adegan kedua ini adalah setelah Kabir menjawab pertanyaan Kia dengan perlahan dan mengangkat alisnya satu kali untuk memberikan tekanan di bagian akhir kalimat. Tubuh Kia menjauh seperti kehilangan kepercayaan terhadap Kabir. Dapat disimpulkan bahwa pertanda pada adegan kedua adalah sosok laki-laki sangat berhati-hati terhadap apa yang menjadi pemikirannya yaitu sama dengan ibunya untuk mengurus rumah tangga dan pasti kontra dengan kondisi lingkungan yang ideal.

Skap hati-hati dari pihak laki-laki ditunjukan dengan sikap tubuh dan intonasi suara sebagai bagian dari komunikasi non verbal yang memperkuat pesan verbal. Setelah menyatakan pendapatnya, Dalam adegan ini, Kabir juga menceritakan bahwa setelah menyelesaikan pendidikannya pada Program Master di Jurusan Bisnis, ia justru tak ingin bekerja dan justru berkeinginan untuk menjalani hidup seperti ibunya, yaitu mengurus segala kebutuhan rumah tanoga. Penekanan dilakukan oleh pihak laki-laki, ima ha baginya menjadi bapak rumah tan ga s. ga menyenangkan dibanding harus menjodi obot su ctu perusahaan dengan tujuan menge ar karir.

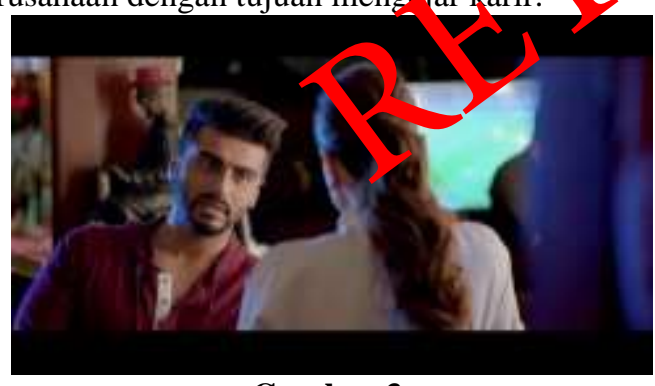

Gambar 3.

Adegan tentang kesetaraan kedudukan laki-laki dan perempuan

Pada adegan ketiga, pesan disampaikan oleh pihak laki-laki yaitu Kabir dengan narasi berikut: "Jika menjadi seperti ayahmu bukanlah suatu masalah lalu apa masalahnya menjadi seperti ibumu? Mereka berdua sama saja.”. Berdasarkan teks tersebut, diperoleh penanda bahwa senyum Kabir menyebabkan Kia tidak berempati. Posisi duduk Kabir yang mencondongkan badannya ke arah Kia sembari menyandar meja menandakan bahwa dirinya berusaha santai untuk menyampaikan pesan yang tidak dianggap normal oleh kebanyakan orang termasuk Kia.

Berdasar dialog dan bagaimana komunikasi non verbal yang ditunjukan tokoh, dapat disimpulkan pertanda dari adegan ini adalah Perempuan yang diwakili sosok Kia berpikiran bahwa perempuan harus bekerja keras dan fokus berkarir sehingga posisinya tidak dibawah laki-laki. Dari sisi laki-laki yang diwakilkan oleh Kabir, menunjukan bahwa ia sepemikiran dengan Kia namun dengan pemikiran lain pula terkait dengan pilihan laki-laki untuk tinggal dirumah dan mengurus semua pekerjaan rumah yang notabene selama ini dilakukan oleh perempuan. Kia sebagai tokoh utama yang feminis ini masih terpengaruh dengan pikiran patriarki, ini dibuktikan semenjak ia bertemu Kabir. Kia masih menganggap bahwa seharusnya laki-laki bekerja di luar rumah bukannya memilih untuk mengurus pekerjaan rumahtangga.

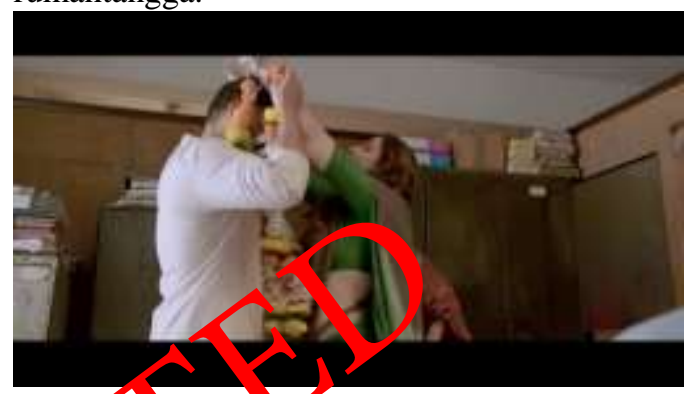

Gan foa 4. Ade Pernikahan Kia dan Kabir Pa abjek penelitian ke empat, menunjukan ahwa Kia dan Kabir memilih untuk menjalani p rnikaban dengan prinsip yang mereka yakini. Pada adegan ini pihak perempuan yang diperankan oleh Kia lebih dulu mengalungkan rangkaian bunga ke leher Kabir untuk ritual Jai Mala. Hal ini berkebalikan dengan normatifnya prosesi pernikahan yang berlangsung di India. Pada adegan ini didukung dengan Backsound lagu berjudul Foolishq (Cinta Gila), dengan melodi pop yang mendayu.

“...Foolishq (Cinta Gila).. Foolishq (Cinta Gila).. Tera Mera (Milik Kita).. Accha $\mathrm{Hi}$ Hai (Bagus sekali jika).. Tedha Medha (Penuh lika-liku)..."

Penanda pada adegan ini adalah Kabir, Kia, dan ibunya sedang tertawa ketika Kia lebih dulu mengalungkan rangkaian bunga ke leher Kabir. Kabir kemudian mengalungkan rangkaian bunga ke leher Kia. Dapat disimpulkan bahwa pertanda dari scene ini adalah dalam budaya patriarki, perempuan seringkali diposisikan sebagai pihak kedua yang berkewajiban menunggu tindakan dari pihak lakilaki. Namun melalui adegan ini perempuan digambarkan sebagai pihak yang cepat dalam mengambil tindakan dan tidak perlu menunggu lakilaki terlebih dahulu. Kia yang mewakili sosok perempuan menggambarkan dirinya sebagai 'Ki' yang berarti laki-laki dalam bahasa Hindi pada budaya patriarki.

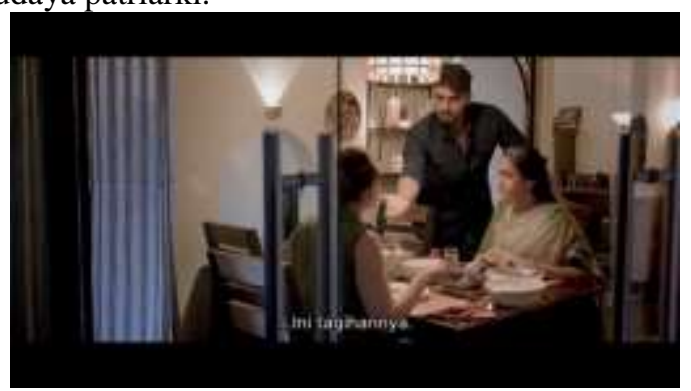

Gambar 5. Adegan Kabir meminta uang belanja pada Kia

Pada objek penelitian kelima terlihat bahwa sosok laki-laki yang diperankan oleh Kabir sedang meminta uang belanja pada pihak perempuan yang diperankan oleh Kia. Hal ini dilakukan tidak dalam ranah personal sebagai pasangan suami istri, namun 
di depan ibu Kia sehingga hal ini dianggap sebagai hal yang wajar ketika mereka berperan untuk bertukar posisi. Berikut ini dialog antara ibu Kia dan Kabir:

Ibu Kia: "Untuk apa semua ini Kabir? Kita bisa pesan."

Kabir: "Di hotel makanan dipesan, di rumah makanan dimasak. Tapi karena kau sangat suka memesan, ini tagihannya. Aku butuh uang untuk mengurus rumah."

Penanda pada adegan ini adalah komunikasi non verbal laki-laki, yaitu Kabir yang menegadahkan tangan yang menunjukan isyarat meminta uang kepada Kia untuk membayar berbagai keperluan rumahtangga. Berdasar dialog yang muncul dan berbagai komunikasi non verbal yang mendukung maka dapat disimpulkan pertanda pada adegan ini adalah perempuan memiliki kedudukan yang lebih tinggi sebagai tulang punggung keluarga dan pencari nafkah bagi laki-laki karena pilihannya sebagai bapak rumahtangga. Laki-laki seringkali digambarkan sebagai pihak yang memiliki ego yang tinggi namun pada adegan ini pihak laki-laki yang diperankan $0^{1}$ en Kabir tidak merasa gengsi walaupun berad pac. posisi nomor dua setelah perempuan. Cal ini dikarenakan sudah adanya kesepakaton di wal pernikahan akan pembagian ers drám rumahtangga dimana hal ini oe ebra gan dengan budaya patriarki.

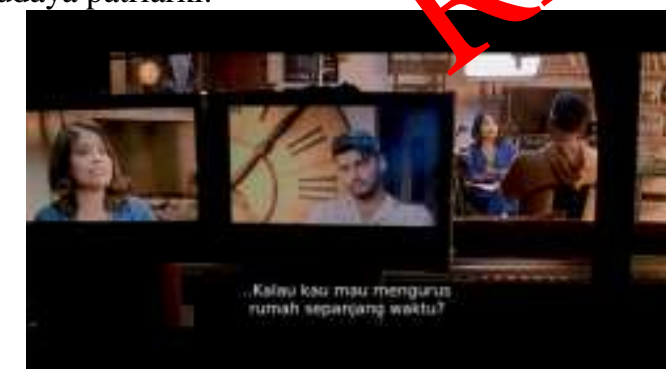

Gambar 6. Adegan Kabir Shooting membahas tentang peranan dalam rumah tangga

Pada objek penelitian ke enam menceritakan tentang bagaimana sosok laki-laki menceritakan pilihan hidupnya dalam menjalani rumahtangga dalam kesepakatan kesetaraan gender. Berikut adalah dialog pada adegan ini:

Host: "Jadi, boleh dibilang dalam hubungan kalian, Kialah suaminya?”

Kabir: "Tidak. Kia tetaplah seorang istri dan aku suaminya. Tapi aku paham kebingunganmu. Mengurus rumah berarti 'wanita' dan berkarir berarti 'pria' menurut 'Tradisi India'.,

Host: "Benar. Tapi, Kia wanita yang sukses dan kau bergantung secara finansial. Apa kau tak merasa tersinggung? Kau tak merasa iri?"'

Kabir: "Jadi kau ingin bilang kalau semua wanita ibu rumah tangga iri dengan kesuksesan suaminya? Menggunakan uangnya untuk mengurus rumah menyinggungnya? Jika wanita tak merasakan itu, kenapa kau berpikir pria akan merasa iri dan tersinggung?"

Penanda pada adegan ini adalah Posisi Kabir yang duduk dengan menyilangkan kedua tangannya di dada dimana hal ini menunjukan bahwa ia tidak setuju pada lawan bicaranya.

Pertanda dari adegan ini adalah lebih menekankan pada bahasa tubuh dari pihak laki-laki yang merasa tidak sepakat akan persoalan kesetaraan gender. Media yang mengundang Kabir sebagai pembicara terkait peranan suami dalam rumah tangga. Berdasar dialog yang muncul pada scene ini, sosok laki-laki yang dip ranka oleh Kabir merasa tidak sepakat pada parny, taan a la label suami dan istri yang beruba ketika colang suami memilih untuk menye esaika pek r Jaan rumah tangga dan tidak bekeria.

Label sy ami dan istri tetaplah melekat pada personal, hanya saja berbeda peran di uma Bag/laki-laki di film ini, peran siapa yang be arir dan yang mengurus rumah tangga itu hanya ersoalan budaya atau tradisi turun temurun. Berdasar érnyataan yang disampaikan di media, Kabir sebagai laki-laki merasa bahwa persoalan peran yang dipilihnya adalah persoalan serius yang tidak lagi berdasar pada keberlanjutan tradisi namun bersifat piliha personal bersama pasangan.

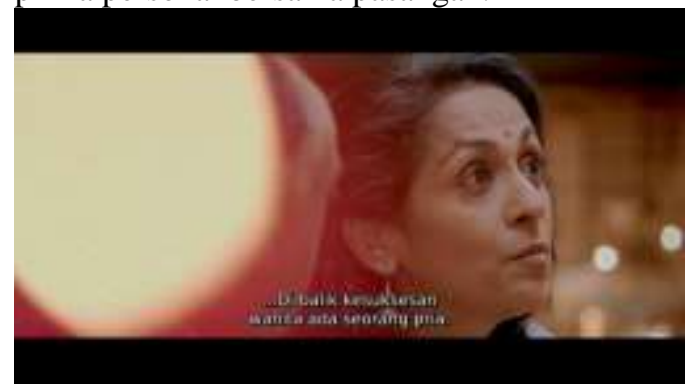

Gambar 7. Adegan Ibu Kia yang Membela Menantunya

Pada objek penelitian yang ketujuh merupakan adegan peranan orangtua yang mendukung langkah anak dan menantunya dalam pertukaran peran dalam rumahtangga. Tokoh yang ditampilkan adalah Ibu dari tokoh perempuan Kia, dan ayah dari Kabir yang menyatakan keyakinannya berikut ini:

Ayah Kabir: "Sampai hari ini kupikir bahwa di balik setiap kesuksesan ada seorang perempuan .

Ibu Kia: Dan anak Anda membuktikan

bahwa di balik kesuksesan perempuan ada seorang laki-laki."

Penanda pada scene ini adalah saat Ibu Kia menjelasan pada Ayah Kabir dengan raut wajah bahagia dan santai mengenai apa yang dilihatnya pada rumahtangga anaknya merupakan hal baik yang mungkin saja terjadi. Maka dapat disimpulkan bahwa pertanda pada scene ini adalah orangtua Kabir, yaitu ayahnya kini menyadari dengan pikiran terbuka bahwa pernikahannya serta jalan hidup yang dipilih 
anaknya untuk menjadi bapak rumah tangga adalah hak anak.

Apa yang ditampilkan pada objek ketujuh, berbeda dengan pernyataan ayah Kabir yang muncul pada objek ke delapan berikut ini:

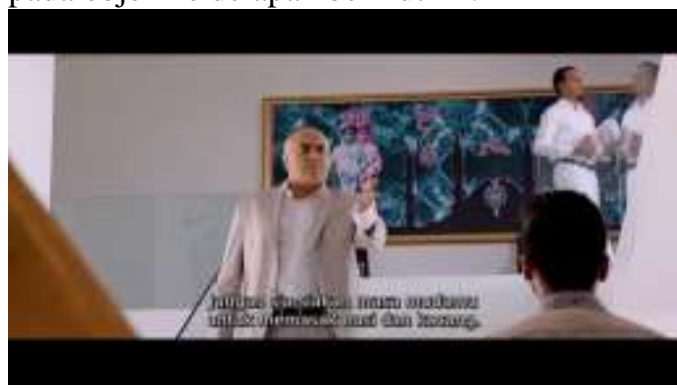

Gambar 8.

Adegan Kemarahan Ayah Kabir

Sebagai seorang Ayah yang memiliki anak laki-laki, ia merasa sangat malu atas pilihan anaknya. Hal ini muncul dalam dialog berikut ini:

"Apa istrimu mengusirmu? Putri Tuan Singhal bekerja di kantor istrimu. Sетиa orang menertawakanku. Aku dapat ucapan bela sungkawa! Malulah sedikit! Jangan sia-siakan masa mudamu untuk memasak nasi dan kacang. Masih ada waktu. Lakukd pekerjaan yang sesungguhnyg Wakt takkan pernah kembali. Takkam add yang menghormatimu!",

Pada adegan ini penanda hya dalah scorang ayah memiliki kebanggaan at memili anak lakilaki dan memiliki latar pandid, an yâng baik. Namun sayangnya, anaknya jo tru mem / posisi yang lebih rendah dari perempuan, altu-cerada di rumah. Ayah Kabir pada scene ini di_ambarkan sebagai sosok antagonis yang tidak mau mendengarkan pendapat anaknya dan cenderung ingin dilihat sebagai orang terhormat dengan kedudukan dan jabatan yang dimilikinya.

Pertanda pada objek penelitian ke delapan adalah kehormatan yang selama ini dibangun oleh laki-laki yaitu Ayah Kabir yang biasanya selalu dihormati oleh seluruh karyawan dan rekan kerjanya justru merasa tidak dihargai oleh anaknya sendiri karena apa yang dipilih oleh anaknya justru menjatuhkan derajat kehormatannya sebagai lakilaki. Hal ini tentu saja menjadi cerminan bagaimana budaya patriarki begitu kuat di budaya India sehingga yang ideal adalah sesuai dengan tradisi yang diyakini, termasuk peran laki-laki dan perempuan dalam rumahtangga.

Ting-Toomey berpendapat bahwa salah satu kompetensi dalam komunikasi antarbudaya adalah proses negosiasi identitas yang efektif di antara dua orang atau lebih yang terlibat dalam komunikasi. Ketika terjadi komunikasi dengan orang lain yang berbeda budaya, maka keahlian untuk menegosiasikan identitas menjadi hal yang penting untuk dilakukan untuk mencapai kesepahaman.

Hasil penelitian ini menunjukkan bahwa seluruh asumsi di atas terpenuhi dalam berbagai scene yang menjadi objek penelitian. Dinamika identitas keanggotaan seseorang di masyarakat nampak pada upaya-upaya Kia dan Kabir dalam menghadapi masyarakat dan meyakinkan masyarakat bagaimana identitas mereka sebenarnya. Dalam seluruh gambar ditunjukkan bahwa upaya mereka menunjukkan identitas tidaklah mudah, ada dinamika yang muncul sebagai dampak perbedaan budaya yang diyakini.

Upaya-upaya orang disekitar Kia dan Kabir dalam konflik menguatkan asumsi bahwa setiap orang-orang dalam semua budaya atau kelompok etnis memiliki kebutuhan dasar akan motivasi untuk memperoleh kenyamanan identitas, kepercayaan, keterlibatan, koneksi dan stabilitas baik level identitas berdasarkan individu maupun kelompok. Dari segi Kia dan Kabir mereka berupaya membuat masyarakat mengerti. Gejolak orano-orang yang berada di sekitar menunjukkan ke utuhar dasar kelompok agar orangorang diseki annya nemi iki nilai yang sama sehingga tercapai ko ein bang atau stabilitas.

Pili on Fia untuk menikah dengan Kabir gerup an be atuk asumsi bahwa setiap orang akan cenderun mengalami kenyamanan identitas dalam suatu lingkungan budaya yang familiar baginya dan cebaliknya akan mengalami identitas yang rentan dalam suatu lingkungan yang baru. Kia sebagai perempuan yang tidak tradisional, begitupula Kabir dan bersatunya keduanya dalam ikatan pernikahan merupakan cara untuk memperoleh keamanan identitas.

Asumsi mengenai setiap orang cenderung merasakan kepercayaan identitas ketika berkomunikasi dengan orang lain yang budayanya sama atau hampir sama dan terjadi kegoyahan identitas ketika berkomunikasi mengenai tema-tema yang terikat oleh regulasi budaya yang berbeda. Kepercayaan identitas berusaha dicapai Kia dan Kabir, sementara kegoyahan muncul di orang-orang sekitar mereka, seperti dari pihak orangtua maupun orang lain yang berada dekat dengan mereka.

Asumsi teori yang berikutnya adalah mengenai seseorang akan cenderung merasa menjadi bagian dari kelompok apabila identitas keanggotaan dari kelompok yang diharapkan memberi respon yang positif. Seseorang akan merasa asing pada saat identitas keanggotaan kelompok yang diinginkan memberi respon yang negatif. Kia dan Kabir masuk dalam asumsi berbeda karena respon negatif lingkungan sekitar mereka, meskipun keduanya dapat saling menerima.

Pada asumsi mengenai seseorang akan mengharapkan koneksi antarpribadi melalui kedekatan relasi yang meaningful (misalnya dalam situasi yang mendukung persahabatan yang akrab) dan sebaliknya akan mengalami otonomi identitas saat mereka menghadapi relasi yang separatis/terpisah. Dalam film ini, ditunjukkan bahwa pemeran Kia dan Kabir berusaha membangun hubungan yang meaningful karena kesamaan identitas, sedangkan mereka terpaksa memiliki 
otonomi identitas karena menghadapi relasi yang separatis dengan lingkungan sekitarnya. Orang akan memperoleh kestabilan identitas dalam situasi budaya yang dapat diprediksi dan akan menemukan perubahan identitas atau goncang dalam situasisituasi budaya yang tidak diprediksi sebelumnya. Tokoh Ayah Kabir menunjukkan bagaimana kegoncangan muncul karena ia menjadi orangtua dari anak yang berbeda jalur hidupnya.

Pada asumsi teori mengenai dimensi budaya, personal dan keragaman situasi mempengaruhi makna, interpretasi, dan penilaian terhadap tema-tema atau isu-isu identitas. Film ini diangkat dari budaya India yang terkenal patriarkal dan fokus pada nilai-nilai kelompok. Oleh karenanya film Ki \& Ka benar-benar menyentil kenyataan yang akan terjadi di masyarakat jika situasi Ki \& Ka benarbenar terjadi. Kepuasan hasil dari negosiasi identitas meliputi rasa dimengerti, dihargai dan didukung. Dalam film ini menggelitik upaya Kia dan Kabir mencari kenyamanan. Akhir film ini menunjukkan adanya kepuasan hasil negosiasi ditandai dengan ayah Kabir yang menjadikan Kia sebagai CEO perusahaan meskipun ia seorang perempuan

Komunikasi antarbudaya yang

pada pentingnya pengintegrasiar engetas an antarbudaya, motivasi, dan ketrrmpilan u, uk dapat berkomunikasi dengan memu skan, tepat, dan efektif. Film ini gan bogai adegan menggambarkan proses "mindfulness". Bagaimana jika kondisi i dan $\mathrm{Ka}$ terjadi di masyarakat dan bagaimana orang-orang di sekitar mereka akan menyesuaikan diri. Film ini mengilustrasikan pengintegrasian apa saja yang dibutuhkan untuk mencapai kepuasan hasil.

\section{KESIMPULAN}

Ki dan Ka adalah sebuah film yang menarik untuk dikaji karena memberikan skenario kemungkinan saat sebuah isu terjadi di masyarakat, yaitu kesetaraan gender dimana perempuan dan laki-laki yang tidak mengikuti peran tradisional mereka. Penelitian ini mendeskripsikan tentang bagaimana representasi kesetaraan gender ditampilkan. Teori yang digunakan pada penelitian ini adalah Negosiasi Identitas. Hasil penelitian menunjukan bahwa film ini mampu menggambarkan seluruh asumsi dalam teori negosiasi identitas, yaitu mengenai bagaimana kenyamanan akan dicapai saat identitas sama dengan sebagian masyarakat, bagaimana konflik sebagai bentuk goyahnya identitas akibat perbedaan dengan budaya dominan. Film $\mathrm{Ki}$ dan $\mathrm{Ka}$ sepanjang durasinya dapat menggambarkan proses negosiasi identitas Kia sebagai perempuan pekerja dan Kabir sebagai laki-laki domestik. Akhir film menunjukkan adanya kepuasan identitas yang terjadi karena adanya penerimaan identitas baik dari sisi para tokoh dan orang di lingkungan mereka. Film ini secara sempurna menggambarkan dinamika negosiasi identitas saat kesetraaan gender berusaha diaplikasikan dalam kehidupan masyarakat.

\section{REFERENSI}

Abbott.1992.Masculine and Feminine. Bandung: Bandar Maju

Arivia, Gadis. (2006). Feminisme. Jakarta: Kompas

Engels, Frederick.(2011).The Guardian. London: Royal Ascot

Permana, F. Y. (2017). Perempuan dalam kampanye antikorupsi. Jurnal Aspikom, 3(3), 399-413.

Nimrah, S., \& Sakaria, S. (2015). Perempuan dan Budaya Patriarlkidalam Politik: Studi Kasus Kegagalan Caleg erempuan dalam Pemilu Legislatiof 2 14. Jirnal Administrasi dan Kebr, $k a>$ Kes latan Indonesia, 1(2), 173 181

Nuroln, A. Z.) (2018). Representasi Feminisme Ra. 'val Melalui Tokoh "Kia” Dalam Film” $\mathrm{Ki}^{2}$ \& Ka”: Ditinjau Melalui Analisis Wacana Kritis (Doctoral dissertation, Institut Seni Indonesia Yogyakarta).

Priyatna Prabasmoro, Aquarrini.(2006). Kajian Budaya Feminis: Tubuh, Sastra, dan Budaya Pop.

Sakina, A. I. (2017). Menyoroti budaya patriarki di Indonesia. Share: Social Work Journal, 7(1), 71-80.

Sari, K. W., \& Haryono, C. G. (2019). HEGEMONI BUDAYA PATRIARKI PADA FILM (Analisis Naratif Tzvetan Todorov Terhadap Film Kartini 2017). SEMIOTIKA: Jurnal Komunikasi, 12(1).

Wadud,

Amina.(2015).Kesetaraan

Gender.Tangerang:Cinta Buku Media

Vera, Nawiroh.(2014).Semiotika dalam Riset

Komunikasi.Bogor: Penerbit Ghalia

Widyawati, A. (2017). Representasi Peran Gender Dalam Film India (Analisis Semiotika Roland Barthes Pada Tokoh Kabir Dalam Film KI AND KA (2016)) (Doctoral dissertation, Universitas Brawijaya).

Yusriana, A., \& Zulfiningrum, R. (2016). Film dan Perempuan: Kegagalan Film Gone Girl Dalam Membentuk Sosok Perempuan Baru di Industri Film Hollywood. Jurnal The Messenger, 8(2), 68-85.

Yusriana, A., \& Nurinsa, A. (2020). PESAN SUBLIMINAL MENGANDUNG UNSUR SEKSUAL DALAM FILM DISNEY COCO. Jurnal Audience: Jurnal Ilmu Komunikasi, 3(1), 99-116.

Zewitra, Z. (2018). Pilihan Kata Sebagai Manifestasi Konsep Kesetaraan Gender Dalam Wacana Kampanye Un Women. JURNAL BAHASA INGGRIS TERAPAN (JOURNAL OF APPLIED ENGLISH), 4(2), 27-40.

Portal Online 
https://www.unocha.org/story/gender-equality-notonly-women-issue-it-everyone, diunduh tanggal 23 Januari 2021 Pukuul 10.53 WIB http//:hukum.unsrat.ac.is/uu/uu_1_74.htm diakses pada tanggal 1 Desember 2020 pukul 11.52 WIB

http://magdalene.co/, diakses pada tanggal 8 November 2020

https://ayononton.online/ki-and-ka-2016/, diakses pada 12 Oktober 2020

https://www.filmapik.co/ki-and-ka, diakses pada 10 Oktober 2020 http://www.nonton33.net/komedi/nonton-ki-and-ka2016/, diakses pada 25 September 2020 http://lk21.pw/ki-ka-2016/, 27 September 2020

\section{PROFIL DENUL 'S}

Wida ti adala dosen di Universitas Bina Sarana arorma ika Fakultas Ilmu Komunikasi dan

Bahasa P Jgram Studi Periklanan.

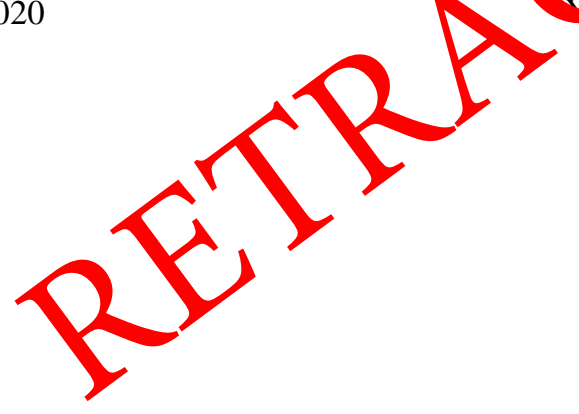

